\title{
PENGARUH KINERJA KEUANGAN TERHADAP PENYALURAN KREDIT PADA BANK PERKREDITAN RAKYAT DI KOTA SEMARANG
}

\author{
Widya Prananta ${ }^{1)}$; Yulianti $^{2)}$; Anita Damajanti ${ }^{3)}$ \\ widyaprananta@mail.unnes.ac.id ${ }^{1)}$;yulianti@usm.ac.id ${ }^{2}$; ; anitadamajanti@usm.ac.id \\ Jurusan Manajemen, Universitas Negeri Semarang, Semarang, Indonesia \\ Jurusan Akuntansi, Universitas Semarang, Semarang, Indonesia
}

\section{Info Artikel}

\section{Sejarah Artikel:}

Diterima : Mei 2019

Disetujui : juli 2019

Dipublikasikan : Agustus

2019

Keywords:

Kinerja keuangan;

Perbankan; Penyaluran

kredit

\begin{abstract}
Abstrak
Penelitian ini bertujuan untuk menguji pengaruh kinerja keuangan BPR terhadap penyaluran kredit di kota Semarang. Data yang digunakan merupakan data sekunder yang diambil dari Laporan Publikasi Otoritas Jasa Keuangan. Data yang diperoleh sebanyak 69 laporan keuangan BPR di Kota Semarang dari tahun 2014-2016. Metode yang digunakan untuk menganalisis data adalah Analisis Regresi Linier Berganda. Penelitian ini menggunakan alat analisis SPSS Versi 16. Hasil penelitian menunjukkan bahwa DPK (Dana Pihak Ketiga), ROA (Return on Asset), NPL (Non-performing Loans), CAR (Capital Adequacy Ratio), dan LDR (Loan to Deposit Ratio) secara bersama-sama memiliki pengaruh signifikan terhadap penyaluran kredit di BPR Kota Semarang. Sementara secara parsial ROA (Return on asset), NPL (Non-performing Loans), CAR (Capital Adequacy Ratio) tidak memiliki pengaruh, sementra DPK (Dana Pihak Ketiga) dan LDR (Loan to Deposit Ratio) memiliki pengaruh yang signifikan terhadap penyaluran kredit sehingga Bank Perkreditan Rakyat harus menghimpun Dana Murah dari Masyarakat agar kredit yang disalurkan memiliki bunga Kredit yang Kompetitif dan menjaga likuiditasnya agar ratio LDR tetap berada di ratio yang ditetapkan Bank Indonesia.
\end{abstract}

\section{THE EFFECT OF FINANCIAL PERFORMANCE ON THE DISTRIBUTION OF CREDITS IN RURALS BANKS IN SEMARANG CITY}

\begin{abstract}
Aim of this study is to examine the influence of the financial perfomance of BPR against credit disbursement in the city of Semarang. The data used is secondary data taken from the Financial Services Otoritas Jasa Keuangan. Data obtained were 69 financial statements of rural banks in the city of Semarang from 2014-2016. The method used to analyze the data is the Analysis of Multiple Linear Regression. This study uses the SPSS Version 16. The results showed that TPF (third party funds), ROA (Return on assets), NPL (Non performing Loans), CAR (Capital Adequacy Ratio), and $L D R$ (Loan to Deposit Ratio) were significantly and together had an effect on lending at the Semarang City BPR. While partially, ROA (Return on assets), NPL (Non performing Loans), CAR (Capital Adequacy Ratio) have no influence while, TPF (third party funds) and LDR (Loan to Deposit Ratio) have a significant effect on lending, so that the Rural Bank must collect Cheap Funds from the Community so that the loans disbursed have Competitive Credit interest and maintain liquidity so that the LDR ratio remains at the ratio set by Bank Indonesia.
\end{abstract}

\footnotetext{
Alamat Korespodensi

Fakultas Ekonomi, Universitas Negeri Semarang, Sekaran, Gunungpati

widyaprananta@mail.unnes.ac.id
} 


\section{PENDAHULUAN}

Sebagai wujud dari hasil yang telah dicapai oleh suatu perusahaan, tidak terlepas dari kinerja yang dilakukan perusahaan. Pentingnya pengukuran kinerja suatu perusahaan yaitu untuk memberikan gambaran baik buruknya perusahaan kepada Pemegang saham sebagai prinsipal dan manajemen perusahaan sebagai pengambil keputusan.

Fungsi dari Bank Perkreditan Rakyat (BPR) adalah untuk menghimpun dana dari masyarakat dan menyalurkannya kepada masyarakat dalam bentuk kredit untuk meningkatkan taraf hidup rakyat banyak. Sektor kredit yang disalurkan oleh BPR mempunyai peranan yang cukup besar terhadap pertumbuhan ekonomi di suatu daerah. Bank Perkreditan Rakyat harus senantiasa menjaga kepercayan masyarakat dengan selalu menunjukan kinerja yang baik, terutama dengan tetap memenuhi ketentuan Prudential Banking Regulation yang mengisyaratkan akan pengelolaan keuangan perbankan yang sehat.

Berdasarkan kutipan dari majalah (Infobank, Juli 2017) menyatakan bahwa industri Bank Perkreditan Rakyat (BPR) masih berada dalam tekanan sepanjang 2016. Tahun lalu komponen kinerja keuangan BPR, seperti kredit, dana pihak ketiga (DPK), maupun aset, tumbuh melambat dibandingkan periode 2015. Data dari Otoritas Jasa Keuangan (OJK) menunjukan, pada kredit tumbuh 9,19\%, DPK tumbuh 12,58\%, dan aset tumbuh $11,59 \%$. Lebih lambat jika dibandingkan dengan kinerja tahun 2015, dalam hal kredit tumbuh 9,38\%, DPK tumbuh 14,50\%, dan aset tumbuh 13,17\%. Tekanan yang harus dihadapi BPR pun tidak hanya dari pertumbuhan bisnisnya yang melambat sebab kualitas kreditnya pun ikut memerah. Menutup tahun 2016, rasio kredit bermasalah atau Non Performing loan (NPL) BPR merangkak naik dari posisi 2015 dari 5,37\% menjadi 5,83\%, bahkan untuk bulan maret 2017 NPL BPR kian memburuk mencapai 6,68\%. Penelitian yang telah dilakukan seperti (Syukriah Selvie et all, 2017) menunjukkan bahwa dana pihak ketiga, suku bunga, dan modal bank berpengaruh secara signifikan dan bersama-sama terhadap penyaluran kredit.

Tingkat kredit macet yang masih tinggi ini, jika tidak tertanggulangi tentunya akan memekan modal perbankan sehingga dapat menurunkan tingkat kecukupan modal atau Capital Adequacy Ratio (CAR). Menurut (Moh Sofyan, 2015) Non Performing loan NPL berpengaruh terhadap penyaluran kredit perbankan tetapi menurut (Gede agus dian mahayoga dan Ni Nyoman Yuliarmi, 2013) mengatakan Non Performing loan NPL tidak berpengaruh terhadap penyaluran kredit BPR di Provinsi Bali. Meskipun penyaluran kredit memegang peranan penting dalam pertumbuhan suatu bank, tetapi bank harus tetap menjaga Likuiditasnya. Hal ini dapat dilihat dari ratio LDR (Loan to deposit ratio).

Semakin tinggi LDR menunjukan semakin besar pula dana pihak ketiga (DPK) yang disalurkan dalam bentuk kredit, yang berarti semakin besar pula potensi pendapatan yang akan diterima. Dana pihak ketiga (DPK) berpengaruh positif dan signifikan terhadap penyaluran kredit (Agus Murdiyanto, 2012). Disisi lain apabila bank memiliki tingkat LDR rendah maka akan menyebabkan kepercayaan masyarakat terhadap bank tersebut akan menurun dikarenakan bank mengalami kesulitan dalam melakukan pengembalian dana dari masyarakat. LDR memiliki presentase tertinggi dalam mempengaruhi penyaluran kredit perbankan (Saryadi, 2013).

Semakin besar ROA maka semakin optimal pula penggunaan aktiva yang dimiliki bank untuk menghasilkan pendapatan. Return on assets termasuk faktor internal bank yang juga biasa digunakan untuk mengukur faktor profitabilitas 
perusahaan perbankan. Menurut (Yua Molek Winarti Putri dan Alien Akmalia, 2015) Return on Assets (ROA) berpengaruh terhadap penyaluran kredit perbankan di Indonesia sedangkan, menurut (Novyanti Nora Purba et all , 2016) Return on Assets (ROA) tidak berpengaruh terhadap penyaluran kredit.

Oleh sebab itu, adanya evaluasi faktor yang mempengaruhi penyaluran kredit pada BPR perlu dilakukan sebagai masukan bagi bank yang diharapkan dapat menjaga ketidakstabilan penyaluran kredit terkait kinerja keuangan BPR sehingga memiliki kekuatan dalam menghadapi persaingan dengan bank-bank lainnya serta implikasi manajerial yang dapat meningkatkan produktivitas perbankan dalam penyaluran kredit.

\section{TELAAH PUSTAKA}

\section{Pengaruh Dana Pihak Ketiga (DPK) Terhadap Penyaluran Kredit}

Dana-dana yang dihimpun dari masyarakat dapat mencapai $80 \%-90 \%$ dari seluruh dana yang dikelola bank dan kegiatan perkreditan mencapai 70\%-80\% dari kegiatan usaha bank (Dendawijaya, 2009). Dari teori tersebut, jumlah DPK suatu bank berbanding searah (positif) dengan penyaluran kredit perbankan dengan kata lain semakin tinggi DPK maka semakin tinggi pula penyaluran kredit perbankan.

Penelitian yang dilakukan oleh (Syukriah Selvie et all, 2017) tentang pengaruh dana pihak ketiga, suku bunga kredit, dan modal bank terhadap penyaluran kredit pada Bank Perkreditan Rakyat Konvensional di Indonesia. Hasil penelitian menunjukkan bahwa Dana pihak ketiga, suku bunga, dan modal bank berpengaruh secara signifikan dan bersama-sama terhadappenyaluran kredit. Selain itu, secara parsial bahwa dana pihak ketiga dan modal bank berpengaruh positif dan signifikan terhadap penyaluran kredit, sementara suku bunga tidak memiliki pengaruh.

$\mathrm{H}_{1}$ : DPK berpengaruh signifikan terhadap penyaluran kredit.

\section{Pengaruh Capital Adequacy Ratio (CAR) Terhadap Penyaluran Kredit}

Permodalan merupakan hal yang pokok bagi sebuah bank, selain sebagai penyangga kegiatan operasional sebuah bank, modal juga sebagai penyangga terhadap kemungkinan terjadinya kerugian. Modal ini terkait juga dengan aktivitas perbankan dalam menjalankan fungsinya sebagai lembaga intermediasi atas dana yang diterima nasabah. Dengan terjaganya modal berarti bank bisa mendapatkan kepercayaan dari masyarakat yang amat penting artinya bagi sebuah bank karena dengan demikian, bank dapat menghimpun dana untuk keperluan operasional selanjutnya (Sinungan, 2000).

Penelitian yang dilakukan oleh (Pangestuti. Irene Rini Demi dan Oktaviani. 2011) tentang Pengaruh DPK, CAR, NPL dan Jumlah SBI terhadap Penyaluran Kredit Perbankan (Studi Pada Bank Umum Go Public di Indonesia Periode 2008-2011). Hasil penelitian yang menggunakan analisis regresi berganda disertai uji asumsi klasik ini terbukti bahwa DPK dan CAR berpengaruh positif dan signifikan terhadap kredit perbankan,sedangkan SBI berpengaruh negatif dan signifikan terhadap kredit perbankan. Selain itu ROA dan NPL tidak berpengaruh terhadap kredit perbankan.

$\mathrm{H}_{2}$ : CAR berpengaruh signifikan terhadap penyaluran kredit.

\section{Pengaruh Non Performing Loan (NPL) Terhadap Penyaluran Kredit}

Kelancaran debitur dalam membayar kewajibannya, yaitu pokok angsuran dan bunga, adalah sebuah keharusan. Karena bank merupakan lembaga intermediasi perbankan yang bertugas menampung dan menyalurkan dana dari dan ke masyarakat. Sehingga pembayaran kredit oleh debitur merupakan sebuah keharusan agar kegiatan operasional bank tetap dapat berjalan dengan lancar. Apabila terjadi banyak penunggakan pembayaran kredit oleh debitur maka berarti bank tidak bisa mendapatkan 
kembali modal yang telah dikeluarkannya, dan hal itu tentu saja dapat mempengaruhi tingkat kesehatan bank dan bisa berefek pada penurunan tingkat kepercayaan masyarakat. Dampak dari keberadaan NPL dalam jumlah besar tidak hanya berdampak pada bank yang bersangkutan, tetapi juga meluas dalam cakupan nasional apabila tidak dapat ditangani dengan tepat.

Penelitian yang dilakukan oleh (Greydi Normala Sari, 2013) tentang FaktorFaktor yang mempengaruhi penyaluran kredit Bank Umum Di Indonesia. Hasil penelitian menunjukkan bahwa DPK, CAR, NPL, dan BI Rate memiliki pengaruh yang signifikan terhadap penyaluran kredit di Indonesia.

$\mathrm{H}_{3}$ : NPL berpengaruh signifikan terhadap penyaluran kredit.

\section{Pengaruh Return On Assets (ROA) Terhadap Penyaluran Kredit}

Semakin besar ROA maka semakin optimal pula penggunaan aktiva yang dimiliki bank untuk menghasilkan pendapatan. Return on assets termasuk faktor internal bank yang juga biasa digunakan untuk mengukur faktor profitabilitas perusahaan perbankan. Bahwa kegiatan perkreditan yang dilakukan bank mencapai 70\%-80\% dari kegiatan usaha bank (Dendawijaya, 2009). Hal tersebut membuktikan bahwa mayoritas kegiatan usaha bank adalah penyaluran kredit. Oleh karena itu, semakin tinggi ROA maka membuktikan bahwa semakin optimal penggunaan aktiva perusahaan untuk memperoleh pendapatan maka berarti kegiatan kredit oleh bank telah dioptimalkan untuk mendapatkan pendapatan.

Penelitian yang dilakukan oleh (Yua Molek Winarti Putri dan Alien Akmalia, 2015) tentang Pengaruh CAR, NPL, ROA dan LDR terhadap penyaluran kredit pada perbankan yang terdaftar di bursa efek indonesia tahun 2011-2015. Hasil penelitian menunjukkan bahwa secara parsial rasio CAR dan ROA berpengaruh positif signifikan terhadap penyaluran kredit perbankan. Rasio NPL berpengaruh negatif signifikan terhadap penyaluran kredit perbankan. Sedangkan rasio LDR tidak berpengaruh signifikan terhadap penyaluran kredit perbankan.

$\mathrm{H}_{4}$ :ROA berpengaruh signifikan terhadap jumlah penyalurankredit

\section{Pengaruh Loan to Deposit Ratio (LDR) Terhadap Penyaluran Kredit}

Loan to deposit ratio adalah rasio yang mengukur kemampuan kredit yang telah disalurkan guna membayar semua dana masyarakat serta modal sendiri. Semakin tinggi Loan to deposit ratio maka kemampuan kredit yang telah disalurkan oleh bank juga semakin tinggi guna membayar kewajiban jangka pendeknya seperti membayar kembali pencairan dana deposan dari kreditur, bunga yang seharusnya diberikan, dan memenuhi permintaan kredit oleh debitur. Menurut anjuran Bank Indonesia, LDR yang aman adalah pada kisaran $78 \%$ sampai $100 \%$. Apabila suatu bank mampunyai tingkat LDR lebih dari $100 \%$, maka harus menambah GWM sebesar $0,2 \%$ untuk setiap peningkatan LDR sebesar 1\%. Untuk memenuhi anjuran Bank Indonesia tersebut, maka bank berusaha untuk menaikkan rasio LDR selama rasio

Penelitian yang dilakukan oleh (Moh.Sofyan, 2015) tentang Pengaruh LDR, CAR, NPL, BOPO, ROA, dan DPK terhadap kredit pada bank perkreditan rakyat (BPR) di Kabupaten Magetan: periode pengamatan tahun 2008 - 2014. Hasil penelitian menunjukkan bahwa secara parsial LDR, NPL, DPK berpengaruh secara parsial terhadap Kredit BPR. Sedangkan CAR, BOPO, dan ROA tidak berpengaruh secara parsial terhadap Kredit BPR.

$\mathrm{H}_{5}$ : LDR berpengaruh signifikan terhadap jumlah penyaluran kredit 


\section{METODE}

\section{Jenis dan Sumber Data}

Penelitian ini menggunakan data sekunderi berupa laporan keuangan Tahunan BPR se Kota Semarang tahun 2014-2016 data time series. Data Sumber data berasal dari laporan publikasi OJK, website resmi OJK yaitu http://www.ojk.go.id. Alasan perlunya pengambilan sampel adalah sebagai berikut,

1. Lebih cepat dan lebih mudah karena menggunakan data sekunder yang tersaji di website OJK.

2. Memberi informasi yang lebih banyak dan lengkap mengenai kinerja keuangan BPR.

3. Keterbatasan waktu, tenaga dan biaya.

\section{Populasi dan Sampel}

Populasi yang digunakan dalam penelitian ini adalah BPR yang berada di Kota Semarang. Sampel penelitian ini adalah BPR di Kota Semarang. Pemilihan sampel dengan menggunakan purposive sampling. Dengan kriteria sebagai berikut,
a. BPR yang melaporkan laporan keuangannya di website OJK.
b. BPR tersebut terletak di Kota Semarang.
c. Laporan keuangannya berisi tentang variabel-variabel yang diteliti.

Dengan menggunakan teknik purposive sampling diperoleh 69 data laporan keuangan, yang diperoleh dari total 23 BPR di seluruh Kota Semarang dengan 3 periode laporan yaitu tahun 2014-2016.

\section{Metode Analisis Data}

Dalam penelitian ini menggunakan metode analisis data Regresi linier berganda menggunakan aplikasi SPSS Versi 16, untuk memperoleh gambaran mengenai hubungan dan signifikansi antar variabel. Dalam menganalisis faktor penentu nilai penyaluran kredit ini, sebelumnya dilakukan pengujian asumsi klasik untuk memastikan bahwa model regresi linier berganda yang digunakan tidak terdapat masalah normalitas, multikolinearitas, heteroskedastisitas, dan autokorelasi. Jika semua itu terpenuhi berarti bahwa model analisis telah layak digunakan.

\section{HASIL DAN PEMBAHASAN}

\section{Statistik Deskriptif}

Dalam penelitian ini ditemukan 21 buah data outlier, sehingga membuat sampel penelitian yang sebelumnya berjumlah 69 menjadi 48 .

Berdasarkan uji statistik deskriptif, dapat diketahui bahwa nilai mean atau ratarata penyaluran kredit adalah sebesar 17,8706 dengan standart deviasi 1,21437, hal ini menunjukan standart deviasi lebih kecil dibandingkan dengan nilai rata-rata (mean) yang berarti bahwa data terdistribusi dengan baik.

Variabel dana pihak ketiga (DPK) memiliki nilai terendah sebesar 15,79 , nilai tertinggi 20,16 dan rata-rata DPK sebesar 17,8273, sedangkan untuk standart deviasi 1,26132. Tingginya nilai rata-rata (mean) dibandingkan standart deviasi mengindikasikan simpangan data DPK baik.

Variabel Capital adequacy ratio (CAR) memiliki nilai terendah sebesar 10,23 dan yang tertinggi sebesar 71,19, sedangkan nilai rata-rata sebesar 24,5221. Berdasarkan uji statistik deskriptif nilai rata-rata(mean) CAR BPR di Kota Semarang 
menunjukan ratio kecukupan modal BPR di Kota Semarang sudah memenuhi standart yang ditetapkan Bank Indonesia minimum 8\%.

Variabel Non Performing Loan (NPL) memiliki nilai terendah sebesar 1,13 dan yang tertinggi sebesar 16,38, sedangkan nilai rata-rata (mean) sebesar 5,5075. Berdasarkan uji satistik deskriptif nilai rata-rata NPL BPR di Kota Semarang menunjukan masih tergolong tinggi karena masih berada diatas 5\% dari standart yang ditetapkan Bank Indonesia.

Variabel return on assets (ROA) memiliki nilai terendah sebesar 0,41 dan yang tertinggi sebesar 11,01, sedangkan nilai rata-rata (mean) sebesar 4,4921. Berdasarkan uji statistik deskriptif nilai rata-rata (mean) ROA BPR di Kota Semarang menunjukan baik karena nilainya masih diatas $1,215 \%$ dari yang ditetapkan oleh Bank Indonesia, artinya kemampuan manajemen bank BPR di Kota Semarang cukup baik dalam memperoleh laba dari total aktiva yang dimiliki.

Variabel Loan to Deposit Ratio (LDR) memiliki nilai terendah 48,86 dan yang tertinggi 98,49, sedangkan nilai rata-rata (mean) sebesar 80,7640. Berdasarkan uji statisktik deskriptif nilai rata-rata (mean) LDR BPR di Kota Semarang menunjukan telah memenuhi standart yang ditetapkan oleh Bank Indonesia, berkisar 80\% - 110\%.

\section{Pengujian Normalitas}

Dalam penelitian ini menggunakan teknik Kolmogorov-Smirnov dalam menguji normalitas data. Hasil uji Normalitas data dapat dilihat pada tabel berikut,

Tabel 1 Uji Normalitas

\begin{tabular}{|cc|r|}
\hline & & \multicolumn{2}{|c|}{$\begin{array}{c}\text { Unstandardized } \\
\text { Residual }\end{array}$} \\
\hline & & 48 \\
Normal & Mean & .0000000 \\
Parameters ${ }^{\mathrm{a}, \mathrm{b}}$ & Std . Dev & .10967163 \\
Most Extreme & Absolute & .107 \\
Differences & Postif & .107 \\
& Negatif & -.074 \\
Kolmogorov -Smirnov Z & .743 \\
Asymp . Sig. (2-tailed ) & .640 \\
\hline
\end{tabular}

Sumber: Data yang diolah

Berdasarkan hasil olah data uji normalitas menunjukan nilai Asymp. Sig (2tailed) adalah 0,640 , Hal tersebut menunjukan nilai diatas 0,5 . Artinya data yang diuji memiliki distribusi normal.

\section{Pengujian Multikolonieritas}

Dalam model korelasi yang baik seharusnya tidak terjadi korelasi diantara variabel-variabel bebas. Berdasarkan hasil olah data Uji Multikolonieritas menggunakan SPSS 16 nilai Tolerance dari kelima variabel (NPL, CAR, LDR, ROA dan DPK) menunjukan lebih dari 0,10 , sedangkan nilai VIF dibawah 10, Artinya tidak terjadi korelasi diantara variabel independen.

\section{Pengujian Heterokedastitas}

Menurut Imam Ghozali uji heterokedastitas bertujuan untuk menguji apakah dalam model regresi terjadi ketidaksamaan varians dari residual satu pengamatan ke pengamatan lainnya. Uji Heterokedastitas pada penelitian ini menggunakan grafik Scatterplot. Hasil uji Heterokedastitas data dapat dilihat pada table berikut ini, 
Tabel 2 Uji Heterokedastitas

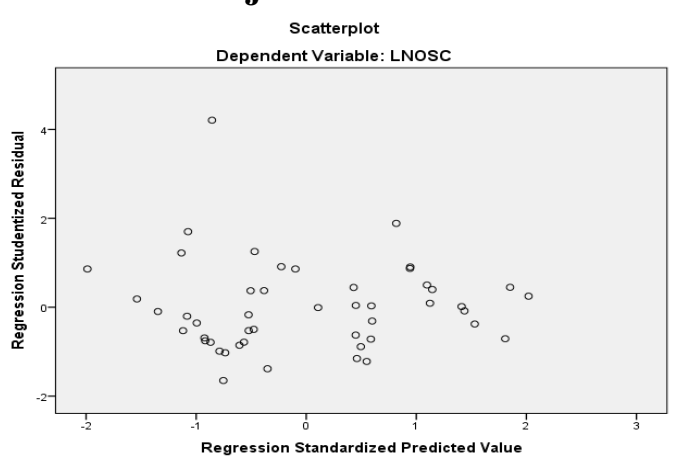

Sumber: Data yang diolah

Berdasarkan hasil olah data uji heterokedastitas menggunakan grafik Scatterplot menunjukan titik-titik pada grafik menyebar acak baik diatas maupun dibawah angka nol, artinya tidak terjadi Heterokedastitas.

\section{Pengujian Autokorelasi}

Dalam pengujian ini bertujuan untukxmenguji apakahxmodel regresi linier terdapat korelasi xantara kesalahan pengganggu pada periode $\mathrm{t}$ dengan kesalahan pengganggu pada periode t-1 (sebelumnya), Model regresi yang baik adalah regresi yang bebas dari autokorelasi. Berdasarkan hasil olah data uji Autokorelasi nilai Asymp. Sig. (2-tailed) adalah 0.013 kurang dari 0,05, maka Ho ditolak dan HA diterima. Hal ini berarti data residual terjadi secara tidak random. Artinya data tersebut tidak terjadi Autokorelasi.

\section{Pengujian Hipotesis}

Pengujian hipotesis pada penelitian ini menggunakan regresi linier berganda. Adapun hasil yang diolah dapat dilihat pada table berikut,

\section{Tabel 3 Uji Hipotesis}

\begin{tabular}{|c|c|c|c|c|c|c|c|}
\hline \multirow[b]{2}{*}{ Model } & \multicolumn{2}{|c|}{$\begin{array}{c}\text { Un } \\
\text { standardized } \\
\text { Coefficients }\end{array}$} & \multirow[b]{2}{*}{ Beta } & \multirow[b]{2}{*}{$\mathrm{t}$} & \multirow[b]{2}{*}{ Sig. } & \multicolumn{2}{|c|}{$\begin{array}{c}\text { Collinearity } \\
\text { Statistics }\end{array}$} \\
\hline & B & $\begin{array}{l}\text { Std. } \\
\text { Error }\end{array}$ & & & & Tlr & VIF \\
\hline (Cons) & -.856 & .464 & & 1.843 & .072 & & \\
\hline NPL & -.002 & .006 & -.004 & -.250 & .804 & .654 & 1.52 \\
\hline CAR & .004 & .002 & .041 & 1.798 & .079 & .381 & 2.62 \\
\hline LDR & .020 & . 003 & .155 & 7.633 & .000 & .472 & 2.11 \\
\hline ROA & -.001 & .010 & -.002 & -.124 & .902 & .496 & 2.01 \\
\hline LNDPK & .958 & .018 & .995 & 53.16 & .000 & .555 & 1.80 \\
\hline
\end{tabular}

Sumber: Data yang diolah 
Berdasarkan hasil olah data uji regresi linier berganda diperoleh persamaan regresi sebagai berikut,

$$
\begin{gathered}
Y=\alpha+\beta_{1} X_{1}+\beta_{2} X_{2}+\beta_{3} X_{3}+\beta_{4} X_{4}+\beta_{5} X_{5}+\varepsilon \\
Y=-0.856-0.02 X 1+0.004 X 2+0.020 X 3-0.001 X 4+0.95 X 5
\end{gathered}
$$

Konstanta sebesar minus 0,856, artinya apabila Dana Pihak Ketiga (DPK), Return on asset (ROA), Non performing loan (NPL), Capital adequacy ratio (CAR), dan Loan Deposit Ratio (LDR) tidak ada atau nilainya adalah 0, maka penyaluran kredit di BPR Kota Semarang nilainya sebesar minus 0,856.

Variabel ratio kredit bermasalah yaitu, Non performing Loan (NPL) memiliki Koefisien regresi negative yaitu sebesar minus 0,02. Nilai Koefisien yang negative menunjukan bahwa NPL terhadap penyaluran kredit berpengaruh negatif. Hal ini menggambarkan bahwa jika terjadi kenaikan nilai NPL sebanyak satu persen maka akan menyebabkan penurunan penyaluran kredit sebesar 0,02 (dalam jutaan rupiah) dengan asumsi variabel lain dianggap konstan.

Variabel ratio permodalan yaitu, Capital Adequacy Ratio (CAR) memiliki nilai Koefisien regresi positif yaitu sebesar 0,004 . Nilai Koefisien yang positif menunjukan bahwa CAR terhadap penyaluran kredit berpengaruh positif. Hal ini menggambarkan bahwa jika terjadi kenaikan nilai CAR sebanyak satu persen maka akan menyebabkan kenaikan penyaluran kredit sebesar 0,004 (dalam jutaan rupiah) dengan asumsi variable lain dianggap konstan.

Variabel ratio kredit dibandingkan dana pihak ketiga, Loan Deposit Ratio (LDR)memiliki nilai Koefisien regresi positif yaitu sebesar 0,020. Nilai Koefisien yang positif menunjukan bahwa LDR terhadap penyaluran kredit berpengaruh positif. Hal ini menggambarkan bahwa jika terjadi kenaikan nilai LDR sebanyak satu persen maka akan menyebabkan kenaikan penyaluran kredit sebesar 0,020 (dalam jutaan rupiah) dengan asumsi variabel lain dianggap konstan.

Variabel ratio laba dibandingkan dengan asset (ROA) memiliki nilai Koefisien regresi negatif yaitu sebesar minus 0,001. Nilai Koefisien yang negatif menunjukan bahwa NPL terhadap penyaluran kredit berpengaruh negatif. Hal ini menggambarkan bahwa jika terjadi kenaikan nilai ROA sebanyak satu persen maka akan menyebabkan penurunan penyaluran kredit sebesar 0,001 (dalam jutaan rupiah) dengan asumsi variable lain dianggap konstan.

Variabel Dana Pihak Ketiga (DPK) memiliki nilai Koefisien regresi positif yaitu sebesar 0,958. Nilai Koefisien yang positif menunjukan bahwa DPK terhadap penyaluran kredit berpengaruh positf. Hal ini menggambarkan bahwa jika terjadi kenaikan nilai LDR sebanyak satu persen maka akan menyebabkan kenaikan penyaluran kredit sebesar 0,958 (dalam jutaan rupiah) dengan asumsi variabel lain dianggap konstan.

\section{Pengujian Koefisien Regresi Secara Simultan (Uji F)}

Uji $\mathrm{F}$ digunakan untuk mengetahui apakah variable independen secara bersama-sama berpengaruh signifikan terhadap variabel dependen. Hasil uji $\mathrm{F}$ dapat dilihat pada tabel berikut ini, 
Tabel 4 Hasil Uji F

\begin{tabular}{|c|r|r|r|r|r|}
\hline Model & $\begin{array}{c}\text { Sum of } \\
\text { Square }\end{array}$ & df & $\begin{array}{l}\text { Mean } \\
\text { Square }\end{array}$ & F & Sig . \\
\hline Reg & 68.746 & 5 & 13.749 & 1021.50 & $.000^{\mathrm{b}}$ \\
Residual & .565 & 42 & .013 & & \\
Total & 69.311 & 47 & & & \\
\hline \multicolumn{6}{|c|}{ Sumber: Data yang diolah }
\end{tabular}

Berdasarkan hasil olah data Uji $\mathrm{F}$ menunjukan $\mathrm{F}_{\text {Hitung }}$ sebesar 102,5 dengan nilai Sig 0,000. Hai ini menunjukan nilai $F_{\text {Hitung }}$ lebih besar dengan $F_{\text {tabel }} 2,44$ dan nilai sig lebih kecil dari 0,05. Artinya Dana Pihak Ketiga (DPK), Return on Asset (ROA), Non Performing Loan (NPL), Capital Adequacy Ratio (CAR), dan Loan Deposit Ratio (LDR) secara bersama-sama berpengaruh signifikan terhadap penyaluran kredit di BPR wilayah Kota Semarang.

\section{Pengujian Koefisien Regresi Secara Parsial (Uji t)}

Untuk mengetahui apakah variable independen berpengaruh terhadap variabel dependen perlu dilakukan Uji t. Hasil Uji t dapat dilihat pada tabel berikut,

\section{Tabel 5 Hasil Uji t}

\begin{tabular}{|c|c|c|c|c|c|c|c|}
\hline \multirow[b]{2}{*}{ Model } & \multicolumn{2}{|c|}{$\begin{array}{c}\text { Unstandardized } \\
\text { Coefficients }\end{array}$} & \multirow[b]{2}{*}{ Beta } & \multirow[b]{2}{*}{$\mathrm{t}$} & \multirow[b]{2}{*}{ Sig. } & \multicolumn{2}{|c|}{$\begin{array}{c}\text { Collinearity } \\
\text { Statistics }\end{array}$} \\
\hline & B & $\begin{array}{l}\text { Std } \\
\text { Error }\end{array}$ & & & & Tlr & VIF \\
\hline (Cons) & -.856 & .464 & & -1.843 & .072 & & \\
\hline NPL & -.002 & .006 & -.004 & -.250 & .804 & .654 & 1.528 \\
\hline CAR & .004 & .002 & .041 & 1.798 & .079 & .381 & 2.628 \\
\hline LDR & .020 & .003 & .155 & 7.633 & .000 & .472 & 2.119 \\
\hline ROA & -.001 & .010 & -.002 & -.124 & .902 & .496 & 2.017 \\
\hline LNDPK & .958 & .018 & .995 & 53.162 & .000 & .555 & 1.803 \\
\hline
\end{tabular}

Sumber: Data yang diolah

Berdasarkan hasil olah data uji t dapat diketahui nilai $t_{\text {Hitung, }}$

a. Variabel Non Performing Loan (NPL) terhadap penyaluran kredit.

Berdasarkan table diperoleh nilai $t_{H i t u n g}$ sebesar minus 0,250 dengan nilai Sig sebesar 0,804 . Hal ini menunjukan bahwa nilai $t_{\text {hitung }}$ lebih kecil dari pada nilai $\mathrm{t}_{\text {Tabel }}$ 2,018 dan nilai sig lebih besar dari pada 0,05. Dengan demikian Ho diterima Ha ditolak. Artinya tidak terdapat pengaruh signifikan antara variable NPL dengan Penyaluran kredit di BPR Kota Semarang. Meskipun NPL menunjukkan nilai yang cukup tinggi namun Bank Perkreditan Rakyat memiliki Capital Adequacy Ratio (CAR) yang cukup tinggi. Sehingga CAR tersebut masih dapat membantu mengcover risiko kredit yang diakibatkan oleh kredit bermasalah. Oleh karena itu kenaikan NPL secara nyata tidak mengakibatkan menurunnya Kredit dan demikian pula sebaliknya.

b. Variabel Capital Adequacy Ratio (CAR) terhadap penyaluran kredit.

Berdasarkan tabel diperoleh nilai $t_{\text {Hitung }}$ sebesar 1,798 dengan nilai sig. Sebesar 0,079 . Hal ini menunjukan bahwa nilai $t_{\text {Hitung }}$ lebih kecil dari pada nilai $t_{\text {Tabel }}$ 2,018 dan nilai sig lebih besar dari pada 0,05. Dengan demikian Ho diterima Ha ditolak. Artinya tidak terdapat pengaruh signifikan antara variabel CAR dengan penyaluran kredit di BPR Kota Semarang. Hal ini mengindikasikan bahwa 
peningkatan atau penurunan CAR selama periode penelitian tidak akan mempengaruhi penyaluran kredit. Semakin besar tingkat CAR maka semakin tinggi kemampuan permodalan bank dalam menjaga kemungkinan timbulnya risiko kerugian kegiatan usahanya, akan tetapi dalam hal ini belum tentu secara nyata dapat mempengaruhi peningkatan jumlah penyaluran kredit pada Bank Perkreditan Rakyat. Selain itu, CAR yang tinggi juga dapat mengurangi kemampuan bank dalam melakukan ekspansi usahanya seperti penyaluran kredit karena cadangan modal yangsemakin besar digunakan untuk menutupi penurunan aktivanya sebagai akibat dari kerugian-kerugian bank yang disebabkan oleh aktiva yang berisiko.

c. Variabel Loan to Deposit Ratio (LDR) terhadap penyaluran kredit.

Berdasarkan tabel dapat diperoleh nilai $t_{H i t u n g}$ sebesar 7,633 dengan nilai sig sebesar 0,000 . Hal ini menunjukan bahwa nilai $t_{\text {Hitung }}$ lebih besar dari pada $t_{\text {Tabel }}$ 2,018 dengan nilai sig dibawah 0,05. Dengan demikian Ho ditolak dan Ha diterima. Artinya terdapat pengaruh signifikan antara variabel LDR dengan penyaluran kredit di BPR Kota Semarang. Dalam teori yang telah dijelaskan sebelumnya, Tingginya LDR akan berdampak semakin meningkatkan penyaluran kredit BPR. Semakin meningkat rasio LDR BPR menandakan bank tersebut mampu menyalurkan dana ke masyarakat dalam bentuk kredit. Apabila bank tidak menyalurkan dananya maka bank akan kehilangan kesempatan untuk memperoleh keuntungan.

d. Variabel Return on Asset (ROA) terhadap penyaluran kredit.

Berdasarkan tabel dapat diperoleh nilai $t_{H i t u n g}$ sebesar minus 0,124 dengan nilai sig sebesar 0,902. Hal ini menunjukan bahwa nilai t Tabel 2,018 dan nilai sig lebih besar dari pada 0,05. Dengan demikian Ho diterima dan Ha ditolak. Artinya tidak terdapat pengaruh signifikan antara variabel ROA dengan penyaluran kredit di BPR Kota Semarang. Sumber dana yang mendominasi penyaluran kredit lebih banyak bersumber dari Dana Pihak Ketiga yang diperoleh dari tabungan, deposito berjangka dan juga dana yang bersumber dari pinjaman dan modal sendiri. ROA yang diperoleh dari pendapatan bunga bank tidak banyak berkontribusi untuk penyaluran kredit pada BPR. Laba yang diperoleh digunakan untuk memenuhi kewajiban bank terhadap pemegang saham, penilai kerja, dan meningkatkan investasi bank.

e. Variabel Dana Pihak Ketiga (DPK) terhadap penyaluran kredit.

Berdasarkan tabel dapat diperoleh nilai $t_{\text {Hitung }}$ sebesar 53,162 dengan nilai sig sebesar 0,000. Hal ini menunjukan bahwa nilai $\mathrm{t}_{\text {Tabel }} 2,018$ dan nilai sig lebih kecil dari pada 0,05. Dengan demikian Ho di tolak, Ha diterima. Artinya terdapat pengaruh signifikan antara variabel DPK dengan penyaluran kredit di BPR Kota Semarang. Dana Pihak Ketiga (DPK) merupakan salah satu faktor yang mempunyai pengaruh terhadap peningkatan penyaluran kredit perbankan pada BPR di Kota Semarang. Berdasarkan hasil estimasi dan penelitian terdahulu, hal ini sesuai dengan teori yang menyatakan bahwa jika Dana Pihak Ketiga meningkat maka jumlah dana yang dimiliki oleh pihak bank bertambah sehingga memungkinkan pihak bank untuk menyalurkan dana tersebut dalam bentuk kredit kepada pihak-pihak yang memerlukan dana. 


\section{PENUTUP \\ KESIMPULAN}

Berdasarkan pengujian hipotesis yang telah dilakukan menggunakan Analisis Regresi Linier Berganda dengan aplikasi program SPSS ver 16, dapat ditarik kesimpulan sebagai berikut; (1) Terdapat pengaruh siginifikan antara variabel DPK dengan penyaluran kredit BPR di wilayah Kota Semarang. Artinya semakin baik Bank Perkreditan Rakyat tersebut menghimpun dananya dari masyarakat semakin tinggi pula dana yang dapat disalurkan ke masyarakat dalam bentuk kredit; (2) Terdapat pengaruh signifikan antara variabel LDR dengan penyaluran kredit BPR di wilayah Kota Semarang. Semakin meningkatnya rasio LDR BPR menadakan bank tersebut mampu menyalurkan dana pihak ketiganya kepada masyarakat, apabila bank tidak menyalurkan dananya maka akan kehilangan kesempatan untuk memperoleh keuntungan. Akan tetapi harus tetap memperhatikan batasan ratio yang telah ditetapkan BI yaitu berkisaran $80 \%$ 110\%; (3) Tidak terdapat pengaruh signifikan antara variabel CAR dengan penyaluran kredit BPR diwilayah Kota Semarang. Selama periode penelitian CAR tidak secara nyata dapat mempengaruhi jumlah penyaluran kredit BPR di wilayah Kota Semarang. Hal ini karena ratio rata-rata BPR di Kota semarang sudah mencapai $24,52 \%$, artinya sudah melebihi dari batasan minimum yang ditetapkan BI sebesar $8 \%$. Hal ini mengindikasikan BPR di Kota Semarang sudah cukup kuat dalam segi permodalan; (4) Tidak terdapat pengaruh signifikan antara variabel NPL terhadap penyaluran kredit BPR di wilayah Kota Semarang. Meskipun ratio rata-rata NPL BPR di Kota Semarang masih menunjukan nilai yang cukup tinggi yaitu 5,5\%, namun Bank Perkreditan Rakyat memiliki CAR yang cukup tinggi pula, sehingga CAR tersebut dapat membantu mengcover resiko kredit bermasalah. Oleh sebab itu kenaikan atau penurunan NPL tidak secara nyata mempengaruhi penyaluran kredit BPR di wilayah Kota Semarang; (5)Tidak terdapat pengaruh signifikan antara variabel ROA terhadap penyaluran kredit BPR di wilayah Kota Semarang. Sumber dana yang mendominasi penyaluran kredit lebih banyak bersumber dari dana pihak ketiga. ROA yang diperoleh dari pendapatan bunga bank tidak banyak berkontribusi dalam penyaluran kredit BPR di wilayah Kota Semarang.

\section{Implikasi Manajerial}

Berdasarkan uji hipotesis pengaruh dana pihak ketiga terhadap penyaluran kredit diperoleh $t_{\text {Hitung }}$ sebesar 53,162 dengan nilai sig sebesar 0,000, Hal ini merupakan pengaruh terbesar dalam penyaluran kredit BPR diwilayah Kota Semarang. Maka oleh sebab itu BPR perlu melakukan langkah-langkah strategis untuk dapat meningkatkan penyaluran kredit, yaitu dengan cara, Bank Perkreditan Rakyat harus terus melakukan pengembangan produk dan inovasi untuk mendapatkan pertumbuhan baik jumlah simpanan maupun jumlah nasabah simpanan pihak ketiga dengan melakukan pendekatan-pendekatan relationship dengan kelompok usaha dan mitra-mitranya disertai dengan perbaikan layanan baik secara fisik maupun non fisik. Bank Perkreditan Rakyat harus dapat menghimpun dana pihak ketiga dengan bunga yang kompetitif sehingga bunga kredit yang disalurkan dapat bersaing dengan bank-bank Umum.

Berdasarkan uji hipotesis variabel Loan to deposit ratio juga berpengaruh terhadap penyaluran kredit BPR di wilayah Kota Semarang dengan nilai t Hitung sebesar 7,633 dengan nilai sig 0,000. Maka perlu dilakukan langkah-langkah strategis seperti, Bank Perkreditan Rakyat harus meningkatkan kemampuan dan menjalankan fungsi intermediasi baik dengan masyarakat maupun dengan lembaga keuangan lain. Bank 
Perkreditan Rakyat harus menjaga likuiditasnya agar ratio LDR tetap berada di ratio yang ditetapkan Bank Indonesia di kisaran 80\% - $110 \%$.

\section{Keterbatasan Penelitian}

Berdasarkan uji hipotesis diperoleh variable independen yang tidak berpengaruh terhadap variabel dependennya yaitu, Variabel Capital Adequacy Ratio (CAR), Non Performing Loan (NPL) dan Return on Asset (ROA), maka diperlukan penelitian yang lebih lanjut menggunakan variabel tersebut.

\section{Agenda Penelitian Mendatang}

Agenda penelitian mendatang dapat diujikan kembali dengan menambahkan variabel-variabel lain dari penelitian yang terdahulu seperti pada penelitian mengenai Jasa Keuangan lainnya. Sampel yang digunakan hanya sebatas di Bank Perkreditan Rakyat di wilayah Kota Semarang, Untuk penelitan mendatang dapat dikembangkan sampel yang lebih luas.

\section{DAFTAR PUSTAKA}

Biro Riset Infobank. 2017. Omong Besar Pertumbuhan Kredit. Majalah Infobank. No.466 Juli 2017 Vol XXXIX.

Dendawijaya, Lukman. 2009. Manajemen Perbankan. Edisi Kedua. Jakarta: Ghalia Indonesia.

Muljono, Teguh Pudjo. 2001. Manajemen Perkreditan Rakyat Bagi Bank Komersil. Yogyakarta: Badan Pendidikan Fakultas Ekonomi UGM.

Murdiyanto, Agus. 2012. Faktor-Faktor Yang Berpengaruh Dalam Penentuan Penyaluran Kredit Perbankan (Studi Pada Bank Umum Di Indonesia Periode Tahun 2006-2011). Jurnal CBAM-FE Unnissula Vol. 1 No.1 December 2012 Page 61-75.

Novyanti Nora Purba, dkk. 2016. Faktor-Faktor Yang Mempengaruhi tingkat Penyaluran kredit Pada BPR konvensional di Indonesia. Jurnal Aplikasi Bisnis dan Manajemen IPB Vol. 2 No.2 Mei 2106.

Pangestuti. Irene Rini Demi dan Oktaviani. 2011. Pengaruh DPK, CAR, NPL dan Jumlah SBI terhadap Penyaluran Kredit Perbankan (Studi Pada Bank Umum Go Public di Indonesia Periode 2008-2011). Jurnal Fakultas Ekonomika dan Bisnis Universitas Diponegoro Vol.1 No.1.

Putri, Yua Molek Winarti dan Alien Akmalia. 2015. Pengaruh CAR, NPL, ROA dan LDR terhadap penyaluran kredit pada perbankan yang terdaftar di bursa efek indonesia tahun 2011-2015. Jurnal Fakultas Ekonomika dan Bisnis Universitas Muhamadiyah Yogyakarta.

Sari, Greydi Normala. 2013. Faktor-Faktor Yang Mempengaruhi Penyaluran Kredit Bank Umum Di Indonesia (Periode 2008.1-2-12.2). Jurnal. EMBA Vol.1 No.3 September 2013, Hal. 931-941. 
Saryadi. 2013. Faktor-Faktor Yang Berpengaruh Terhadap Penyaluran Kredit Perbankan (Studi Pada Bank Umum Swasta Nasional Devisa). Jurnal. Administrasi Bisnis Universitas Diponegoro Volume 2 Nomor 1 Maret 2013.

Selvie, Syukriah, Muhammad Arfan dan Syukrly Abdullah. 2017. Pengaruh dana pihak ketiga, suku bunga kredit, dan modal bank terhadap penyaluran kredit pada Bank Perkreditan Rakyat Konvensional di Indonesia. Jurnal Pascasarjana Universitas Syiah Kuala. Vol 6 No.02 Mei 2017 Page 52-58

Siamat, Dahlan. 2004. Manajemen Lembaga Keuangan-Kebijakan Moneter dan Perbankan. Jakarta: Fakultas Ekonomi Universitas Indonesia.

Sinungan, Muchdarsyah. 2000. Manajemen Dana Bank. Jakarta: PT Bumi Aksara.

Sofyan, Moh. 2015. Pengaruh LDR, CAR, NPL, BOPO, ROA, dan DPK terhadap kredit pada bank perkreditan rakyat (BPR) di Kabupaten Magetan: periode pengamatan tahun 2008 - 2014. Jurnal Eksekutif Vol 12 No 2 Desember 2015.

Yuliarmi, Ni Nyoman dan Gede Agus Dian Maha Yoga. 2013. Faktor-Faktor Yang Mempengaruhi Penyaluran Kredit BPR Di Provinsi Bali. Jurnal. Ekonomi Pembangunan Universitas Udayana Vol.2 No.6 Juni 2013.

Universitas Semarang. 2016. Pedoman Penyusunan Pelitian Dosen. Fakultas Ekonomi. Semarang: Universitas Semarang.

www.ojk.go.id 